\title{
Antônio Vieira, profeta e missionário. Um estudo sobre a pseudomorfose e a contradição ${ }^{1}$
}

\author{
ALFREDO BOSI
}

I

\begin{abstract}
A ENVERGADURA excepcional desse homem de ação, de imaginação e de expressão exige constantes releituras. Novos perfis aparecem por trás da fisionomia que tínhamos a presunção de conhecer, e que acabam solicitando interpretações mais abrangentes ou matizadas. Se é verdade o dito de Aristóteles segundo o qual não há ciência do individual, ou seja, se a predicação de um só indivíduo é inefável (na acepção do que não pode ser dito), na medida em que a singularidade não é preenchida por epítetos classificatórios, então, o que é possível fazer é cercar os traços mais salientes da persona cultural que a História nos legou, e, à proporção que os reconhecemos, verificar se são consonantes ou entre si contraditórios.

Creio que o maior benefício que recebemos dessa cautela metodológica, avessa a sínteses precoces, é evitar a imersão precipitada das trajetórias pessoais em grandes complexos histórico-literários. No caso, evitar a definição prévia e categórica de Vieira como orador maneirista, sermonista barroco, crente sebastianista ou mente contra-reformista, qualificações que, postadas na porta de entrada do discurso, nos fazem correr o risco de reduzir o múltiplo ou o incoerente a uma compacta uniformidade, paralisando a tarefa analítica e impedindo o reconhecimento das fraturas, contradições e oscilações que uma longa e acidentada trajetória costuma comportar. Entretanto, se, em última instância, a análise dessas fraturas, contradições e oscilações nos levar de volta àquelas mesmas classes abrangentes, confirmando-as, pelo menos teremos detectado ao longo da travessia certos movimentos internos e diferenciais que as definições prematuras podem encobrir.

Este preâmbulo foi motivado pela releitura de dois conjuntos discursivos da obra de Vieira: a defesa que ele fez, perante a Inquisição, de suas interpretações messiânicas das trovas do sapateiro Bandarra (1665-1667); alguns sermões e documentos que redigiu sobre a questão da liberdade dos índios tanto no seu período maranhense (década de 1650) como por ocasião do seu Voto sobre os acordos feitos com os paulistas a respeito da administração dos aldeamentos de Piratininga (1694).
\end{abstract}


Trata-se manifestamente de discursos díspares quanto à matéria, ao tempo e ao lugar que os motivaram. Então, por que aproximá-los? Porque ambos têm a ver com o propósito de método, já esboçado, de contemplar diferenças e mapear desequilíbrios internos antes de enfeixá-los no termo conceitual, que se arriscaria a ser um termo-término, ponto final de um conceito que se pretenderia definitivo.

Vistos à distância de mais de três séculos, tanto aqueles discursos messiânicos como os missionários poderiam, grosso modo, ser qualificados como expressões de um mirífico projeto de construção e glorificação de um vasto império que fosse ao mesmo tempo cristão, universal e português.

Esse império, que Vieira define como Quinto, por seguir-se aos quatro da Antigüidade (assírio, persa, de Alexandre e romano), teria sido prefigurado na estátua do sonho de Nabucodonosor decifrado pelo profeta Daniel; e caberia aos portugueses, com a ressurreição de D. João IV, a derrota final dos otomanos, a extinção das heresias, a conversão e reunião das doze tribos de Israel e, por extensão, a catequese dos gentios espalhados pelos novos mundos conhecidos ou ainda por descobrir. Com o seu advento haveriam de florescer universalmente a paz, a justiça, a inocência e a santidade em todos os estados. Transcrevo em seguida passagens do profeta Daniel na versão em português da Bíblia de Jerusalém:

29 Enquanto estavas sobre o teu leito, ó rei, acorriam-te os pensamentos sobre o que deveria acontecer no futuro, e aquele que revela os mistérios te deu a conhecer o que deve acontecer.

30 Quanto a mim, este mistério me foi desvendado, não porque eu tenha mais sabedoria do que os outros viventes, mas para se manifestar ao rei a interpretação, a fim de que possas conhecer os pensamentos do teu coração.

31 Tiveste, ó rei, uma visão. Era uma estátua. Enorme, extremamente brilhante, a estátua erguia-se diante de ti, de aspecto terrível.

32 A cabeça da estátua era de ouro fino; de prata eram o seu peito e os braços; o ventre e as coxas eram de bronze;

33 as pernas eram de ferro; e os pés, parte de ferro e parte de argila.

34 Estavas olhando, quando uma pedra, sem intervenção de mão alguma, destacou-se e veio bater na estátua, nos pés de ferro e de argila, e os triturou.

35 Então se pulverizaram ao mesmo tempo o ferro e a argila, o bronze, a prata e o ouro, tornando-se iguais à palha miúda na eira de verão: o vento os levou sem deixarem traço algum. E a pedra que havia atingido a estátua tornou-se uma grande montanha, que ocupou a terra inteira.

36 Tal foi o sonho. E agora exporemos a sua interpretação, diante do rei.

$37 \mathrm{Tu}$, ó rei, rei dos reis, a quem o Deus do céu concedeu o reino, o poder, a força e a honra;

38 em cujas mãos ele entregou, onde quer que habitem, os filhos dos homens, os animais do campo e as aves do céu, fazendo-te soberano deles todos, és tu que és a cabeça de ouro.

39 Depois de ti se levantará outro reino, inferior ao teu, e depois ainda um terceiro reino, de bronze, que dominará a terra inteira. 
40 Haverá ainda um quarto reino, forte como o ferro, como o ferro que reduz tudo a pó e tudo esmaga; como o ferro que tritura, este reduzirá a pó e triturará todos aqueles.

41 Os pés, que viste, parte de argila de oleiro e parte de ferro, designam um reino que será dividido: haverá nele parte da solidez do ferro, uma vez que viste ferro misturado à argila de oleiro.

42 Como os pés são parcialmente de ferro e parcialmente de argila de oleiro, assim esse reino será parcialmente forte e, também, parcialmente fraco.

$43 \mathrm{O}$ fato de teres visto ferro misturado à argila de oleiro indica que eles se misturarão por casamentos, mas não se fundirão um com o outro, da mesma forma que o ferro não se funde com a argila.

44 No tempo desses reis o Deus do céu suscitará um reino que jamais será destruído, um reino que jamais passará a outro povo. Esmagará e aniquilará todos os outros reinos, enquanto ele mesmo subsistirá para sempre.

45 Foi o que pudeste ver na pedra que se destacou da montanha, sem que mão alguma a tivesse tocado, e reduziu a pó o ferro, o bronze, a argila, a prata e o ouro. O grande Deus manifestou ao rei o que deve acontecer depois disso. O sonho é verdadeiramente este, e digna de fé é a sua interpretação.

A sucessão dos quatro impérios é confirmada no capítulo 7, em que Daniel conta e interpreta as visões das quatro feras monstruosas que lhe haviam aparecido em sonho. Do mesmo modo que na visão da estátua, o último reino será destruído, sobrevindo a chegada de um ser extraordinário, que nesse mesmo capítulo é chamado Filho do Homem. "A ele foi outorgado o império, a honra e o reino, e todos os povos, nações e línguas o serviram. Seu poder é um poder eterno que jamais passará, e seu reino jamais será destruído" (Dan 7,14 ). "O último reino será derribado e julgado por um tribunal" (Dan 7, 26). "E o reino e o império e as grandezas dos reinos sob todos os céus serão entregues ao povo dos santos do Altíssimo. Seu império é um império eterno, e todos os impérios o servirão e lhe prestarão obediência" (Dan 7, 27).

A interpretação corrente (embora não consensual) da profecia de Daniel tanto nas edições católicas como nas protestantes da Bíblia descodifica esse Quinto e último reino como o que se erguerá com a segunda vinda de Cristo. Será o Reino de que falam os Evangelhos, tantas vezes chamado Reino de Deus ou Reino dos Céus.

Há passagens do Novo Testamento que presentificam o alcance da expressão afirmando que o Reino de Deus está, aqui e agora, em vós, no sentido de "dentro de vós", ou então entre vós, no sentido de "no meio de vós". Em Lucas $(17,21)$ :

entòs hymon, no original grego;

intra vos, na Vulgata;

inwendig in euch, na versão alemã de Lutero;

within you, na versão King James;

a tradução inglesa da Bíblia de Jerusalém prefere among you, o que se verifica também na versão francesa, au milieu de vous. 
A New International Version of the Holy Bible (NYV), largamente difundida nos países de língua inglesa, traz no corpo do texto within you e, em nota, also among. Ambas as leituras estão abonadas na lição da Bíblia calvinista, cuja edição em português, a Bíblia de Estudo de Genebra, registra igualmente dentro de vós, mas em nota faculta a expressão no meio de vós, esclarecendo que esta última locução "aponta para a presença do reino na pessoa de Jesus".

Continua em aberto a exegese no que diz respeito à essência espiritual ou à imanência histórica do Reino de Deus. E até hoje há teólogos que discutem acaloradamente (às vezes, acidamente) a questão, como ficou notório faz poucos anos, quando a Teologia da Libertação foi argüida de imanentista pela ortodoxia vaticana. ${ }^{2}$

Vieira, de todo modo, não tinha dúvida alguma a respeito do caráter dual mas convergente do Reino, chamando-o Império Consumado de Cristo e atribuindo-lhe tanto a dimensão espiritual como a temporal. A temporal seria gerida por um monarca português; a espiritual, por um angélico pastor e pontífice. O reino teria corpo e alma, matéria política e sentido místico. É significativo que Vieira haja visualizado de modo progressivo ou dinâmico a formação desse reino, pois afirma que já começara com a pregação de Cristo (leitura literal, rente ao versículo de Lucas e às 70 ocorrências da palavra Reino nos evangelhos sinóticos), mas que, contrariamente à exegese estática engessada pela Inquisição, o reino, apenas "incoado", continuara a crescer ao longo dos séculos para só "consumarse” no Quinto Império então iminente. A História dos homens teria, portanto, um sentido: seria a história da salvação universal.

É essa a matéria comum a várias obras suas, a começar pela infausta carta que escreveu em 1659 a seu confrade, o Pe. André Fernandes, bispo do Japão e confessor da rainha Luísa, a quem desejava consolar pela morte de D. João IV: trata-se das Esperanças de Portugal ou Quinto Império do Mundo. ${ }^{3} \mathrm{O}$ documento, apropriado pelo Santo Ofício, constituiu a peça-chave do processo que Vieira iria sofrer a partir de 1663. Em 1664, retoma a redação da História do futuro, cujo Livro Anteprimeiro é entregue ao rei Afonso em 1665. ${ }^{4}$ Os rascunhos da parte inicial da História do futuro foram transcritos e luminosamente apresentados por Adma Muhana com o título de Apologia das coisas profetizadas (Vieira, 1994).

Pouco depois, vem a Representação dos motivos que tive para me parecerem prováveis as proposições de que se trata divididos em duas partes, defesa escrita entre hemoptises e acessos de malária no cárcere de Coimbra entre 1666 e 1667, e editada com o título Defesa perante o Tribunal do Santo Ofício, em 1957, por obra de Hernâni Cidade (Vieira, 1957). O manuscrito de ambas as Representações guarda-se no Arquivo Nacional, a Torre do Tombo em Lisboa, e não foi sem emoção que pude compulsá-lo há vinte e tantos anos, quando pesquisava textos de Vieira que me serviriam para a redação do capítulo que lhe dedicaria em um livro sobre a cultura no Brasil colonial. Desse mesmo período é a Defesa 
do livro intitulado Quinto Império, que é a apologia do livro Clavis Prophetarum e respostas das proposições censuradas pelos senhores Inquisidores: dada pelo Padre Vieira estando recluso nos cárceres do Santo Ofício de Coimbra (Vieira, 1856). Finalmente, o ponto de fuga de toda a sua longa elaboração profética, a Clavis Prophetarum, em parte inclusa na História do futuro e trabalhada de modo intermitente desde, pelo menos, 1649 até a estada em Roma (1669 a 1675) e os últimos anos de vida transcorridos na Bahia (1681-1697). É obra que espera a hora da sua publicação e tradução integral.

Identificar a matriz ideológica de Vieira como homem do século XVII, patriota e jesuíta, nacional e supranacional, leva ao pressuposto historicista stricto sensu da uniformidade e coerência do espírito de época, sem dúvida grato ao nosso entendimento, que outra coisa não pede senão repousar no conforto de um conceito-síntese. Mas a história, que é feita também de meandros, pede ao pesquisador atentas vigílias antes do descanso reparador. Daí a necessidade de voltar ao exame dos documentos e sobretudo ao entendimento das reações abertamente hostis que a formulação daquele grandioso e quimérico propósito - nacional e messiânico - suscitou em contemporâneos de Vieira, os quais eram também portugueses, também católicos e também interessados em exercer misteres de dominação, quer como partícipes dos excedentes da empresa colonizadora, quer como agentes do Santo Ofício. ${ }^{5}$

O fato é que o tribunal reprovou em termos drásticos as proposições proféticas de Vieira: uma era estranha ao consenso geral dos Católicos; outra era errônea, ofensiva aos ouvidos pios; outra escandalosa, temerária, igualmente ofensiva aos ouvidos piedosos e com sabor a heresia; outra temerária e falsa; outra, além de errônea, injuriosa para os Santos Padres, para a Sagrada Escritura e para a Igre$j a$; e finalmente, a última, que admitia a incorporação na Igreja das doze tribos hebraicas desaparecidas, foi condenada como sacrílega e injuriosa para a Igreja. Diante desse ingrato conflito entre partes tão desiguais, juízes e réu, precisaríamos de um historicismo aberto, sensível às tensões pontuais peculiares a cada momento da história.

Começando pelo processo movido pela Inquisição portuguesa às interpretações "milenárias" e "judaizantes" que Vieira teria dado a certas passagens dos profetas e às trovas de Bandarra, o que temos como fulcro da acusação?

O que o Santo Ofício, respaldado na ortodoxia escolástica do Concílio de Trento, condenava em Vieira era, em última análise, "a sua crença na vinda iminente de um Reino terrestre, que se estabeleceria sob os poderes de um imperador português, rei ressuscitado e verdadeiro salvador temporal da humanidade dividida pelas discórdias e pela injustiça”.

$\mathrm{Na}$ leitura que o réu fazia daquelas trovas proféticas, toda a "história do futuro" já estava predeterminada, incluindo a própria data do advento messiânico, 1666, número de ressonâncias apocalípticas... (Apocalipse 13, 18: "Aqui é preciso discernimento! Quem é inteligente calcule o número da Besta, pois é 
um número de homem: seu número é 666!" - soma das letras de César-Deus, em grego). Há uma passagem em que Vieira considera João Evangelista, o presumido autor do Apocalipse, como "o cronista do nosso tempo", o que dá a medida da sua crença na atualidade e na iminência dos sucessos profetizados nas Escrituras.

Predeterminada também estava a figura do Encoberto, ressuscitado e encarnado na pessoa de um rei português, D. João IV, que morrera em 1656. É preciso lembrar que, nessa altura, Vieira já descartara a crença na volta de D. Sebastião, referindo-se polemicamente à "crença dos sebastianistas", que, no entanto, ele abraçara em escritos juvenis. Na verdade, o sebastianismo ainda não morrera e sobreviveria por longo tempo na poesia e na cultura rústica portuguesa e nordestina... mas essa é outra história.

Convém dizer que o inquisidor-mor era dominicano, pertencente a uma ordem então poderosa que se agastara com certas alusões satíricas a sermões gongóricos de um de seus pregadores feitas por Vieira no Sermão da sexagésima. Nada como a vingança de um orador arranhado nas suas veleidades literárias...

O que o inquisidor exigia do réu, recluso na cela de um convento em Coimbra, era a admissão pública do caráter alegórico, não-literal, da expressão "Reino de Deus", usada reiteradamente nos escritos que anunciavam o próximo Império luso e universal. Afirmar que o reino seria também temporal e terreno sabia, segundo os inquisidores, a heresia e a judaísmo. Na defesa, Vieira alega em seu favor a imagem da pedra, figurada em Daniel $(2,35)$, que, rolando do alto, viria derrubar a estátua e destruiria até o último império (dos romanos), ao qual sobreviria o Quinto Império, da terra, e na terra: "a pedra cresceu e se fez como um grande monte, o qual encheu toda a terra" ["lapis autem qui percusserat statuam factus est mons magnus, et implevit universam terram"].

Essa é matéria da Representação Primeira, quando trata da natureza do Quinto Império. Leiam-se, em particular, as Questões $5^{a}, 6^{a}$ e $7^{a}$.

A $5^{a}$ está assim formulada: "Se o Quinto Império, que resolvemos ser de Cristo, é Império do Céu ou da terra?".

Na série de exames feitos pelo inquisidor Fr. Alexandre da Silva já em fins de 1666, o tema volta de modo obsessivo. Cito:

Décimo Exame acerca do réu dizer que o Reino e Império de Cristo Senhor Nosso, na Terra, fora e era não somente espiritual senão também temporal, que já hoje é questão disputada "pro utraque parte".

Décimo quinto Exame em que com alguns lugares da Escritura se mostra ser o Reino e Império de Cristo espiritual somente, e não temporal, e terreno como o réu ainda insiste que é e há de ser.

Décimo sétimo Exame em que se trata de argüir e convencer ao réu, contra o dito $5^{\circ}$. Império terreno e temporal futuro de Cristo, com os mesmos textos de Zacarias e Daniel, com que ele procura introduzi-lo e prová-lo. (Vieira, 1957, v.II, p.300-56) 
Bastaria que Vieira se retratasse incondicionalmente e declarasse com todas as letras que estava lidando com uma figura, no caso, uma alegoria, e não com a expressão de um fato empírico, um reino visível e habitável, para que o Santo Ofício o absolvesse. Mas Vieira preferiu arrazoar com os juízes sofrendo por dois anos a pressão do Tribunal, porque se convencera da efetividade histórica das profecias do Bandarra, desconsiderando sentenças da Inquisição que haviam proibido a difusão das Trovas por julgá-las passíveis de interpretações judaizantes. E, acima de tudo, ele as defendia tenazmente porque o advento do Quinto Império universal de inocência, paz e justiça era o seu sonho mais caro. Ainda que contrastado em nome da ortodoxia inquisitorial, o réu o acalentava obstinadamente, contra não poucas evidências, das quais não terá sido a menos desalentadora a passagem em branco daquele tão esperado e mítico ano de 1666. Vieira só sairia do cárcere no final do ano seguinte... e sem permissão de pregar em Portugal. É bem verdade que o papa Clemente X iria isentá-lo das "Inquisições de Portugal e mais reinos" mediante um breve promulgado em Roma aos 17 de abril de 1675, mas, como diria Tomás Antônio Gonzaga, as glórias que vêm tarde já vêm frias.

O leitor culto de nossos dias talvez pasme ao perceber o candor com que um homem da estatura de Vieira dissertava sobre a ressurreição próxima de um rei morto havia dez anos. No entanto, esse homem é o mesmo a quem Cristina da Suécia, discípula de Descartes, escolheria para diretor espiritual nos seus anos romanos. E mais se espantará quando ler a justificação do réu, que declara ter feito uma "diligência" (diríamos hoje uma pesquisa), a qual "sem ser tão esquisita [escrupulosa, minudente] como eu quisera, nem estar acabada, já tinha descoberto, nesses 120 últimos anos, 95 mortos ressuscitados; pois assim como ressuscitaram 95, que muito seria que fossem 96?" (Vieira, 1957, v.I, p.192).

O monarca redivivo fundaria o Quinto Império que duraria mil anos, até que sobreviessem os tempos do anti-Cristo e, finalmente, o dia do Juízo. Aqui confluem o traço mais arcaico e o mais futuroso do milenarismo. Vieira imagina um tempo ideal que nunca existiu, a não ser nas dobras de um desejo coletivo de justiça e paz.

Ao longo da sua defesa, Vieira distinguia com nitidez a imagem do rei terreno do Quinto Império e a figura cristã do Messias, Jesus Cristo, que viera ao mundo uma primeira vez, ressuscitara e voltaria tão-só no final dos tempos para julgar os vivos e os mortos, conforme reza o credo católico. ${ }^{6}$ Entretanto, a má-fé ou a má vontade dos inquisidores suspeitava que, por trás das profecias de Bandarra e de Vieira, se escondessem formas de messianismo judaico à espera daquele senhor de um reino "da terra, e na terra". Acresce que as simpatias do réu pelos "homens de nação", ou "gente de nação", como então se denominavam os judeus, eram notórias e se haviam tornado manifestas nos conselhos que Vieira dera a D. João IV no sentido de obstar à expulsão dos mercadores cristãos-novos. ${ }^{7}$ Como se sabe, foram os capitais desses que lastrearam a Com- 
panhia das Índias Ocidentais defendida ardorosamente por Vieira e fundada em 1649 sob D. João IV. A simpatia de Vieira para com os cristãos-novos e judeus não passaria, de resto, despercebida pelos inquisidores, como o atesta o trecho da sentença que inclui entre as suas culpas ter afirmado

que para a conservação deste reino [de Portugal], era necessário admitirem nele judeus públicos, por serem os que conservam o comércio, de que procediam as forças do mesmo reino; e que enquanto neste, em tempo de certo rei [alusão provável ao reinado de D. Manuel, o Venturoso], se permitiram os tais judeus, fora ele muito mais opulento em riquezas e em poder, como agora são a república de Holanda, e outras, onde os próprios judeus se passaram, depois de serem expulsos de Portugal. Que não há dúvida que os inquisidores faziam no santo ofício os cristãos judeus. ${ }^{8}$

Entre as medidas que Vieira propusera a D. João IV, três, pelo menos, deveriam soar particularmente ousadas no contexto ideológico do Portugal seiscentista:

Primeiro, que Vossa Majestade fizesse nobre a mercancia, de maneira que não só não tirasse, mas desse positiva nobreza, ficando nobres todos os homens que fossem mercadores, não só os que se chamam de sobrado, sendo também os de vara e côvado; com que muitas pessoas de maior qualidade e cristãos velhos se aplicarão ao exercício mercantil, em grande utilidade do reino, a exemplo de Veneza, Gênova, Florença e outras repúblicas, em que os príncipes são mercadores, e elas por isso opulentíssimas.

Segunda, que todo o homem de nação seja hábil para qualquer ofício, honra ou mercê das que não requerem exame e limpeza. Terceira, que nos que requerem exame e limpeza, se faça o exame pelo que toca à fé, e não pelo que pertence ao sangue. ${ }^{9}$

Em outras passagens, defendia que as fazendas dos mercadores fossem livres do fisco (proposta que devia aborrecer mortalmente os inquisidores e seus familiares) e que pudessem celebrar-se casamentos mistos de cristãos e judeus. Também pedia que fosse suprimida a distinção entre cristãos-velhos e cristãosnovos. ${ }^{10}$

No Sermão de São Roque, pregado em 1644 na Capela Real em comemoração ao primeiro aniversário de príncipe D. Afonso, Vieira deixa entrever os pressupostos de seu pensamento político em uma linha que remete, embora obliquamente, a doutrinas da razão de Estado abraçadas pela cultura contra-reformista. Trata-se do notório compromisso jesuítico entre o discurso providencialista e a prática de medidas utilitárias de natureza econômica. Na sua campanha pela admissão de empréstimos de banqueiros cristãos-novos por parte da Coroa na fundação da Companhia das Índias Ocidentais, o pregador desenvolve o topos do perigo que é remédio. No caso, o perigo viria da origem judaica do dinheiro, que serviria de meio não-cristão para colimar fins sublimes, desejados por Deus para maior glória de Portugal. Como os trinta dinheiros pelos quais Judas vendeu Cristo e que, no entanto, serviram para a compra de um terreno onde 
seriam sepultados os peregrinos da Cidade Santa, e figurariam no escudo de Portugal por ordem de Cristo a D. Afonso Henriques. Vieira conclui em um estilo que recorda o não-confessado, reprimido mas sublimado maquiavelismo de Giovanni Botero na sua Ragion di stato: "A razão disto qual é? A razão é porque a bondade das obras está nos fins, não está nos instrumentos. As obras de Deus todas são boas; os instrumentos de que se serve podem ser bons e maus". ${ }^{11}$

Os argumentos do Tribunal, inspirados em preconceitos anti-semitas que recrudesciam no século XVII em toda a península, podem dar-nos uma pista para compreender a mente de Vieira: estranha mescla de fantasias míticas e planos políticos bem concretos afins ao projeto de aliança estrutural do Estado com o mercantilismo burguês em ascensão.

Em artigo pioneiro, publicado em Letras e Artes, em $1^{\circ}$ de maio de 1949, Otto Maria Carpeaux (2001, p.409-12) faz considerações sobre o teor ambivalente do que seria a "ideologia" do Padre Vieira. O texto, intitulado "Aspectos ideológicos do padre Vieira", lembra a posição doutrinária dos jesuítas a favor da aceitação canônica dos juros, instituição capitalista por excelência. Em oposição aos dominicanos e aos teólogos do Santo Ofício, Vieira tomava atitudes que hoje nos parecem mais "realistas" e pragmáticas, isto é, conformes à nova estrutura econômica dos estados monárquicos europeus. Reis, fidalgos e altos prelados, carentes de capitais, não poderiam deixar de pedir empréstimos a juros a banqueiros e financistas, a maioria dos quais judeus ou cristãos-novos. É sabido que recorrer a emprestadores de dinheiro fora uso corrente nas comunas italianas e na corte francesa ao longo dos séculos XV e XVI, para não falar das práticas da corte pontifícia.

Teríamos, de um lado, a burguesia mercantil e financeira ligada ao poder monárquico por fortes laços econômicos, incluindo os relativos à empresa colonial, e, de outro, estamentos tradicionalistas, em geral parasitários, como a nobreza fundiária, a máquina inquisitorial e o clero, excetuando-se, nesse caso, um jesuíta valido do trono, como o foi Vieira durante o reinado de D. João IV.

Não é evidentemente, porém, essa trama de interesses mercantis e desígnios políticos que aparece nos escritos messiânicos de Vieira. Os seus argumentos são fundamentalmente religiosos, as fontes são profetas do Velho Testamento, Daniel, Jeremias, Isaías e o cantor dos Salmos, Davi. E as referências próximas são as trovas de um homem sem letras, mas que Vieira reputava inspirado, o sapateiro Bandarra, que vivera nos meados do século XVI em uma vila da Beira chamada Trancoso. O horizonte é o Quinto Império de paz e justiça universal regido por um monarca português. A sua credulidade medieval povoada de visões, profecias, milagres e ressurreições (pelo menos 95 certas!) parece não ter incorporado a cultura renascentista, como se a mente letrada nutrida pela Contra-Reforma houvesse regredido a um universo pré-moderno, mítico, acrítico.

Como enfrentar hermeneuticamente esse amálgama de estilo e imaginário pré ou antimoderno com um desígnio estruturalmente burguês? 
Carpeaux propõe a vigência de um procedimento ideológico e estilístico peculiar a certos momentos altamente conflitivos, em que o antigo e o moderno entram em aliança contraditória, tensa, pela qual uma linguagem antiga ou antiquada veicula (e ao mesmo tempo, encobre) uma mensagem moderna; ou, viceversa, uma linguagem moderna veicula (ou oculta) um pensamento conservador se não reacionário. Esse procedimento se chama pseudomorfose, termo cunhado pelo historiador Spengler, construtor de sínteses históricas. ${ }^{12}$

Pseudomorfose quer dizer forma ou estilo não transparente ou não correspondente à mensagem latente no discurso. Sempre que essa mensagem traz nas suas dobras um conteúdo que não pode ser expresso explícita e plenamente, porque não terá entrado ainda de pleno direito no consenso dos seus receptores, o discurso precisa assumir uma forma mediadora ou tradicional, que supõe valores capazes de serem mais facilmente acolhidos.

Não se trata propriamente de mascarar fraudulentamente intenções ideológicas, o que seria a pura retórica do engodo. Se admitimos que se aninhava, de fato, uma ideologia mercantil-burguesa no pensamento de Vieira, essa ideologia apareceu (ou precisava aparecer) inteiramente sublimada no seu sonho de edificar um império universal que antecipasse o Juízo Final mediante a instauração de um governo poderoso, justo e pacífico. Assim ficava idealizado e santificado o Estado monárquico português, único capaz de distribuir justiça a todos os povos, incluindo os hebreus perseguidos desde a Diáspora.

Teríamos uma fusão (digna de estudo em termos de história das mentalidades) de discursos religiosos, proféticos e messiânicos, e projetos econômico-políticos. Para usar de linguagem weberiana, assim como a ética calvinista reforçou, se não forjou o espírito capitalista, sem que se possa falar, a rigor, de hipocrisia, dobrez ou farsa ideológica, o profetismo abraçado por Vieira não só justificou, mas também exalçou a idéia do poder material inerente à idéia de império.

Respondendo à questão $18^{\mathrm{a}}$ dos inquisidores, "Quais serão os principais instrumentos desta consumada obra de conversão e sujeição universal do Mundo a Cristo?" - pondera o réu: "Porque tal é a condição das cousas humanas, que nunca as espirituais e divinas se conseguiram, cresceram e conservaram neste Mundo, se não assistidas, defendidas e ajudadas poderosamente das temporais".

Seguem-se numerosos exemplos de pensamento francamente realista extraídos das Escrituras. Transcrevo o primeiro:

A primeira casa que teve Deus neste Mundo, que foi o Tabernáculo, Moisés quis Deus que lha edificasse, e não Arão; porque ainda que ao ofício e dignidade de Arão, como Sumo Sacerdote, pertencesse mais propriamente aquela obra, Moisés tinha o governo temporal e político, e sempre são mais prontos os efeitos deste poder, quando ele toma o serviço de Deus por sua conta. (Vieira, 1957, t.II, p.68-9, 12) 
O modelo supremo viria da relação estreita entre poder temporal e poder espiritual consumada havia séculos pela conversão do imperador Constantino ao cristianismo, que teria efetuado a transmissão da potestas imperial romana à Igreja até então perseguida pela mesma instância dominadora. Vieira, como jesuíta e contra-reformista, exalta o que a Reforma de Lutero e Calvino condenara expressamente: a romanização da Igreja de Cristo.

Esse discurso crítico caminha em um sentido que carrearia águas para a tese ilustrada do caráter "maquiavélico" das práticas jesuíticas tais como se exerceram junto às cortes dos estados monárquicos ao longo do século XVII. O efeito político daquela retórica era promover a conjunção dos poderes reais com os eclesiásticos, consagrando o projeto de uma Igreja universal triunfante aliada às dinastias reinantes. Vieira aspirava, contudo, à ascensão de um único monarca e de um único Império, pois, observava com argúcia, que a rivalidade entre os reis católicos (da França, da Espanha, de Portugal, da Áustria) era causa de guerras constantes e divisões no seio da própria Igreja. O advento daquele imperador cristão todo-poderoso e portador da paz universal sublimava o seu patriótico desejo de que ele saísse de um tronco lusitano. Sonhos gestados no período de abatimento e sujeição do reino à Coroa de Espanha, "aquela noite eterna de sessenta anos tão compridos" "13 que se seguiu ao desastre de Alcácer Quibir e ao desaparecimento de Dom Sebastião? Provavelmente.

Na mente dos inquisidores, ao contrário, aquela conexão, auspiciada por Vieira, de um monarca absoluto com a burguesia financiada por cristãos-novos gerava um mal-estar profundo. Ameaçava deslocar o eixo do poder político para a consecução de um projeto "progressista" e pragmático, no caso, desestabilizador da velha e renitente aliança da Coroa com o alto clero e a nobreza parasitária. Esses estamentos conservadores, em que se apoiava a Inquisição, viviam dos excedentes e dos confiscos, não pagavam impostos e exigiam "pureza" de sangue dos candidatos a cargos públicos. Vieira, em de seus mais ousados sermões (Sermão da terceira dominga do Advento), relativizara o valor da aristocracia de sangue e conclamara o primeiro e o segundo estados, a nobreza e o clero, a concorrerem com seus bens para restaurar o erário do Estado dessangrado após tantos anos de dominação espanhola. O pregador ia, portanto, no sentido contrário daqueles mesmos estratos conservadores: "A verdadeira fidalguia é a ação. O que fazeis, isso sois, nada mais".

A tensão exigia um discurso mediador, de consenso religioso, para resolver-se a contento das forças em contraste. Mas mesmo supondo a vigência da pseudomorfose, é forçoso admitir que Vieira extrapolou e acabou rompendo as barreiras da ortodoxia convencional. Pregar o advento iminente de um reino de Deus neste mundo era, no mínimo, forçar o sentido das profecias bíblicas. E mais extravagante ainda era partir das trovas de um sapateiro "iluminado", que escrevera fazia um século, para propor como absolutamente certa a ressurreição de D. João IV. A elucubração de Vieira abriu-lhe o flanco aos desafetos e deu ocasião 
aos inquisidores de julgá-lo herético. Vieira foi condenado a não mais pregar em terras portuguesas e, naturalmente, a pagar as custas do processo. A sua influência junto à Coroa decresceu verticalmente. A monarquia lusitana preferiu seguir o caminho da subordinação de sua economia à Inglaterra atendo-se apenas à rotineira produção agrícola (videiras e olivais), continuando a sustentar a nobreza e a máquina inquisitorial, enfim abdicando de qualquer projeto industrial. $\mathrm{O}$ que adveio não foi o Quinto Império universal, mas o "reino cadaveroso" que se estenderia dos fins do século XVII até à morte de D. João V. A burguesia teria de esperar pela ação de um déspota esclarecido, o marquês de Pombal, nos meados do século XVIII, para voltar a ter acesso ao favor monárquico.

(Continua no próximo número)

Notas

l O autor agradece aos colegas João Adolfo Hansen e Adma Muhana, promotores do Seminário Internacional comemorativo dos 400 anos do nascimento de Vieira, o convite para proferir a conferência de que este ensaio é desdobramento.

2 O que parece distinguir os significados da expressão Reino de Deus no Novo Testamento das várias interpretações milenaristas ou messiânicas é a certeza absoluta, que nessas se manifesta, do momento histórico em que deverá ocorrer o seu advento. Os Evangelhos descartam explicitamente qualquer tentativa de localizar e datar com precisão a chegada do Reino. Em vez da marcação temporal, as Escrituras acentuam a qualidade e a condição moral ou existencial, lato sensu, que prepararia e permearia, aqui, agora e em qualquer tempo, a emergência do Reino. Nesse sentido, o Reino já está em nós e entre nós, mas ainda não levedou toda a massa de que fala a parábola do fermento. A "proximidade do Reino" seria qualitativa, intra-subjetiva e interpessoal e não pontualmente cronológica. Leia-se, a propósito, o denso texto de Paul Ricoeur (2006).

3 Recomendo a edição transcrita e anotada por José van den Besselaar (2002).

4 Para a História do futuro, ver a edição preparada por Maria Leonor Carvalhão Buescu (Vieira, 1982).

5 Para o conhecimento das obras dos contendores de Vieira, ver Besselaar (2002). O quadro político e ideológico da época foi traçado por Eduardo d'Oliveira França (1951).

6 Ver, em particular, os parágrafos 395 a 401, da Representação Segunda, em Vieira (1957, v.II, p.148-53).

7 Leiam-se as Razões apontadas a El-Rei D. João IV a favor dos cristãos novos, para se lhes haver de perdoar a confiscação de seus bens, que entrassem no comércio deste reino (Vieira, 1856, t.II, p.21-7); a Proposta feita a El-Rei D. João IV em que se lhe representava o miserável estado do Reino e a necessidade que tinha de admitir os judeus mercadores que andavam por diversas partes da Europa (ibidem, p.29-47); enfim, a Proposta que fez ao Serenissimo Rei D. João IV a favor da gente de nação sobre a mudança dos estilos do Santo Ofício e do Fisco em 1646 (ibidem, p.49-75).

8 Ver Sentença que no Tribunal do Santo Ofício de Coimbra se leu ao Pe. Antônio Vieira em 23 de dezembro de 1667 (Vieira, 1856, t.I, p.157). 
9 Ver Proposta que se fez ao sereníssimo rei D. João IV a favor da gente de nação pelo Padre Antonio Vieira sobre a mudança dos estilos do Santo Ofício e do fisco em 1646 (Vieira, 1856, t.II, p.65).

10 Ver Proposta que se fez ao Serenissimo Rei D. João IV... (Vieira, 1856, p.65).

11 Ver Sermão de São Roque (Vieira, 1959, v.III, 8, p.80).

12 Remeto a uma passagem da História da literatura ocidental (Carpeaux, 1960, v.II, p.716-7).

13 Ver Sermão de São Roque pregado na Capela Real por ocasião do primeiro aniversário de nascimento do príncipe D. Afonso (1644) (Vieira, 1959, v.III, 8, p.57).

Referências bibliográficas

BESSELAAR, J. van den. Antônio Vieira. Profecia e polêmica. Rio de Janeiro: EdUerj, 2002 .

CARPEAUX, O. M. História da literatura ocidental. Rio de Janeiro: O Cruzeiro, 1960. v.II.

Ensaios reunidos, Rio de Janeiro: Topbooks, 2001. v.II.

FRANÇA, E. d'O. Portugal na época da Restauração. São Paulo, 1951. Tese (Doutorado) - Faculdade de Filosofia, Ciências e Letras, Universidade de São Paulo.

RICOEUR, P. A hermenêutica bíblica. São Paulo: Loyola, 2006.

VIEIRA, A. (Pe.) Obras inéditas do Padre Antonio Vieira. Lisboa: Ed. J. M. C. Seabra \& T. Q. Antunes, Rua dos Fanqueiros, 82, 1856. t.I.

Obras inéditas do Padre Antonio Vieira. Lisboa: Ed. J. M. C. Seabra \& T. Q. Antunes, Rua dos Fanqueiros, 82, 1856. t.II.

Defesa perante o Tribunal do Santo Ofício. Introd. e notas Hernâni Cidade. Salvador: Livraria Progresso Ed., 1957.

Sermões. Porto: Lello, 1959.

História do futuro. Ed. Maria Leonor Carvalhão Buescu. Lisboa: Imprensa Nacional; Casa da Moeda, 1982. tovia, 1994.

Apologia das coisas profetizadas. Apresentação de Adma Muhana. Lisboa: Co-

RESUMO - O ensaio busca analisar dois aspectos ideológicos e semânticos da obra de Antônio Vieira: a pseudomorfose (tema da primeira parte) e a contradição. A pseudomorfose ou falsa forma é uma figura pela qual a camada superficial do texto não corresponderia à sua mensagem profunda: baseado em profecias bíblicas e nas trovas de Bandarra, Vieira cria a imagem de um Quinto Império universal e cristão sob a qual, porém, se pode detectar o projeto de um vasto império português. Quanto à contradição (tema da segunda parte), a obra missionária de Vieira revela agudo contraste entre a luta pela liberdade dos índios do Maranhão e a aceitação do trabalho escravo dos negros africanos. Verificase também contradição entre essa atitude conformista e a veemente defesa da igualdade de todos homens criados pelo mesmo Deus e redimidos pelo mesmo Salvador. 
PALAVRAS-CHAVE: Antônio Vieira, Profetismo, Escravidão, Missões, Literatura brasileira, Literatura portuguesa.

ABSTRACT - This essay aims at analysing two ideological and semantic aspects of Antônio Vieira's works: the pseudomorphosis (theme of the first part) and the contradiction. The pseudomorphosis or false form is a figure through which the superficial layer of the text would not correspond to its deeper message: based on biblical prophecies and Bandarra's ballads, Vieira creates the image of a universal and Christian Fifth Empire under which, however, one may distinguish the project of a vast Portuguese empire. As to the contradiction (theme of the second part), Vieira's missionary works reveal an acute contrast between the struggle for freedom of the indigenous people from Maranhão and the acquiescence in the enslavement of black Africans. One may also perceive contradiction between this conformist attitude and the vehement defence of equality among all men created by the same God and redeemed by the same Savior.

KEYWORDS: Antônio Vieira, Prophetism, Slavery, Missions, Brazilian literature, Portuguese literature.

Alfredo Bosi é titular de Literatura Brasileira na Universidade de São Paulo e pertence à Academia Brasileira de Letras. Publicou, entre outras obras, História concisa da literatura brasileira, O ser e o tempo da poesia, Céu, inferno, Dialética da colonização, Machado de Assis: o enigma do olhar, Literatura e resistência e Brás Cubas em três versões. É editor de ESTUDOS AVANÇADOS. @ - abosi@usp.br

Recebido em lo.9.2008 e aceito em 8.9.2008. 